\title{
Bioorthogonal Chemical Reporters for Analyzing Protein Sulfenylation in Cells
}

\author{
Thu H. Truong ${ }^{1}$ and Kate S. Carroll ${ }^{2}$ \\ ${ }^{1}$ Department of Chemistry, University of Michigan, Ann Arbor, Michigan \\ ${ }^{2}$ Department of Chemistry, The Scripps Research Institute, Jupiter, Florida
}

\begin{abstract}
Protein sulfenylation (RSOH), the redox-based modification of cysteine thiol side chains by hydrogen peroxide $\left(\mathrm{H}_{2} \mathrm{O}_{2}\right)$, is an important mechanism in signal transduction. Likewise, dysregulated protein sulfenylation contributes to a range of human pathologies, including cancer. Efforts to elucidate the diverse roles of protein sulfenylation in physiology and disease have been hampered by the lack of techniques to probe these modifications in native environments. To address this problem, selective chemical reporters have been developed for the detection and identification of sulfenylated proteins directly in cells. In the approach described here, a cyclic $\beta$-diketone warhead is functionalized with an azide or alkyne chemical handle. An orthogonally functionalized biotin or fluorescent reporter is then appended to the probe post-homogenization via click chemistry for downstream analysis. These bi-functional probes are exquisitely selective for protein sulfenyl modifications, non-toxic, and do not perturb intracellular redox balance. These reagents have been utilized to investigate sulfenylation in vitro and to identify intracellular protein targets of $\mathrm{H}_{2} \mathrm{O}_{2}$ during cell signaling. These methods provide a facile way to detect protein sulfenic acids and to study the biological role of cysteine oxidation with regard to physiological and pathological events. Curr. Protoc. Chem. Biol. 4:101-122 (C) 2012 by John Wiley \& Sons, Inc.
\end{abstract}

Keywords: thiol modification $\bullet$ protein sulfenylation $\bullet$ redox signaling $\bullet$ click chemistry $\bullet$ in-gel fluorescence $\bullet$ western blotting

\section{INTRODUCTION}

Although historically viewed as purely harmful, recent studies demonstrate that hydrogen peroxide $\left(\mathrm{H}_{2} \mathrm{O}_{2}\right)$ functions as an important physiological regulator of intracellular signaling pathways, including cell growth and proliferation (Rhee, 2006; Dickinson and Chang, 2011). In this context, $\mathrm{H}_{2} \mathrm{O}_{2}$ is produced by a family of membrane-bound NADPH-dependent oxidases whose expression is tightly regulated, compartmentalized, and tissue-specific (Lambeth, 2004). The downstream effects of $\mathrm{H}_{2} \mathrm{O}_{2}$ are mediated by covalent modification of cysteine residues found within redox-sensitive target proteins (Reddie and Carroll, 2008; Paulsen and Carroll, 2010). Oxidation of these specific and reactive cysteine residues in turn can lead to modulation of protein activity, much like $O$-phosphorylation (Rhee et al., 2000).

Sulfenic acid (RSOH), also known as sulfenylation, is the direct product of cysteine modification by $\mathrm{H}_{2} \mathrm{O}_{2}$. The reactivity of a cysteine thiol toward $\mathrm{H}_{2} \mathrm{O}_{2}$ is profoundly influenced by the protein environment. Important factors include accessibility and proximity to side chains that may interact with the thiol, peroxide, or the oxidized product. Most reactive are cysteine residues with low $\mathrm{p} K_{\mathrm{a}}$ values that exist as the nucleophilic thiolate anion at physiological $\mathrm{pH}$. However, other factors are undoubtedly involved, as the documented reactivity of protein thiolate anions with $\mathrm{H}_{2} \mathrm{O}_{2}$ ranges across seven orders of magnitude (1 to $10^{7} \mathrm{M}^{-1} \mathrm{sec}^{-1}$ ) (Winterbourn, 2008). Some of these factors are being revealed, but

Current Protocols in Chemical Biology 4: 101-122, June 2012

Published online June 2012 in Wiley Online Library (wileyonlinelibrary.com).

DOI: $10.1002 / 9780470559277 . c h 110219$

Copyright (C) 2012 John Wiley \& Sons, Inc.

Bioorthogonal

Reporters for

Protein

Sulfenylation

101

Volume 4 
consensus motifs have not yet emerged and the understanding of the molecular basis of sensitivity toward $\mathrm{H}_{2} \mathrm{O}_{2}$ for a given cysteine residue remains largely ill-defined.

Once formed, sulfenyl modifications can be stabilized by the microenvironment or, in some cases, react with nearby protein or exogenous thiols to form disulfides (Fig. 1A). Indirect evidence for the formation and stabilization of sulfenic acid in proteins was first reported for the glycolytic enzyme GAPDH in the 1970s (Benitez and Allison, 1974), but was not fully appreciated until detailed biochemical and structural analysis of NADH peroxidase in the late 1990s (Yeh et al., 1996; Crane et al., 1997). These landmark studies led to the discovery that sulfenyl groups function as catalytic redox centers (Wood et al., 2003), alter enzyme chemistry (Salmeen et al., 2003), and act as reversible sensors of $\mathrm{H}_{2} \mathrm{O}_{2}$ levels in microbial transcription factors (Zheng et al., 1998). Under conditions of oxidative stress, sulfenyl groups can also oxidize further to sulfinic $\left(-\mathrm{SO}_{2} \mathrm{H}\right)$ or sulfonic acid $\left(-\mathrm{SO}_{3} \mathrm{H}\right)$. On the other hand, mounting evidence also points to the existence of specialized enzymes that mediate the direct reduction of the sulfenyl modification back to the thiol state (Depuydt et al., 2009).

Historically, methods to detect reactive cysteines and $\mathrm{H}_{2} \mathrm{O}_{2}$-mediated oxidation of protein thiols required homogenization of cells, which disrupts the native environment (Leonard and Carroll, 2011). Under these crude conditions, cellular redox balance and protein structure are compromised, leading to artifactual oxidation during sample processing. The severity of this issue cannot be disregarded and greatly increases the challenges associated with identifying sites of modification in low-abundance proteins, as well as in interpreting the biological significance of the data.

To overcome this problem, small-molecule probes that enable sulfenylated proteins to be trapped and tagged directly in cells have been developed (Reddie et al., 2008; Leonard et al., 2009; Paulsen et al., 2011). In this approach, a cyclic $\beta$-diketone warhead (2; Fig. 1C) that is chemically selective for sulfenic acids known as dimedone (Benitez and Allison, 1974) (1; Fig. 1B) is functionalized with an azide (3 to 5; Fig. 1C) or alkyne (6 to 8; Fig. 1C) reporter group. An orthogonally functionalized biotin or fluorescent tag is then appended post-homogenization for detection via the Staudinger ligation (Saxon and Bertozzi, 2000) or Huisgen [3+2] cycloaddition (i.e., Click chemistry) (Rostovtsev et al., 2002). In addition, two complementary isotope-coded probe pairs to quantify changes in protein sulfenylation (9, 10; Fig. 1C) have been developed (Seo and Carroll, 2011; Truong et al., 2011). Most recently, we have reported tri-functional probes to monitor reversible oxidation of protein tyrosine phosphatases (PTPs) composed of a warhead bearing the cyclic $\beta$-diketone group, a binding module that targets the probe to the PTP active site, and an azide chemical reporter (11, 12; Fig. 1C) (Leonard et al., 2011).

The Basic Protocols present a series of methods utilizing probes for in vitro detection of sulfenyl modifications within recombinant purified proteins (see Basic Protocol 1) and in situ detection in cultured mammalian cells (see Basic Protocols 2 and 3). Labeled sulfenylated proteins can then be visualized by either immunoblot analysis (see Basic Protocol 4) or in-gel fluorescence (see Basic Protocol 5) after being coupled to a biotin or fluorescent tag. Overall, the general approach provides a facile method for profiling sulfenyl modifications in proteins.

Ongoing development of chemical tools for selective detection of protein sulfenylation and other cysteine "oxoforms" is crucial for the progression of this rapidly growing area of research. While it is known that cysteine residues are the primary target of $\mathrm{H}_{2} \mathrm{O}_{2}$ (Paulsen and Carroll, 2010), and that sulfenylation can lead to dramatic changes in protein function, the knowledge regarding individual sites, extent, or dynamics of these modifications in cells is still in an early phase. Acquiring such information is a key step in delineating the molecular mechanisms that underlie redox-dependent control of 


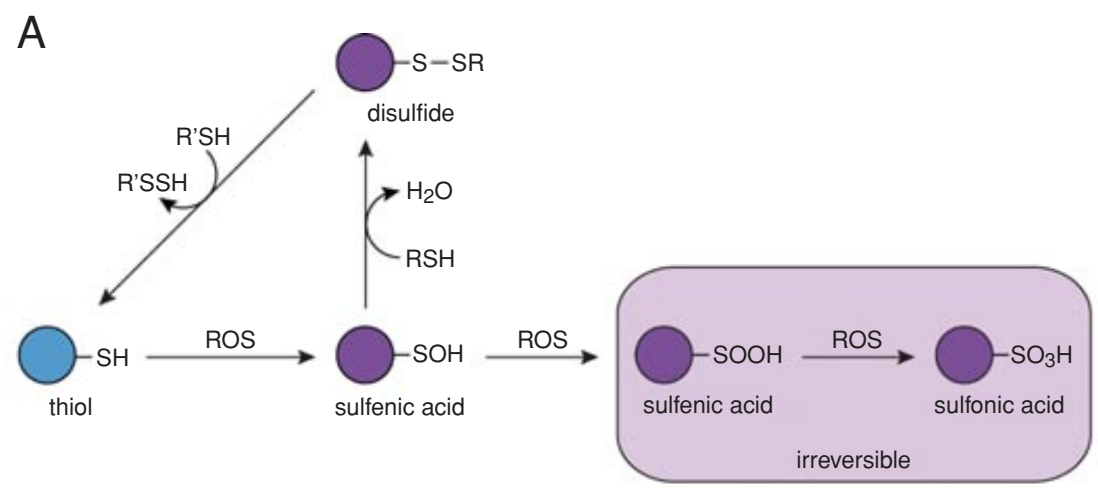

B

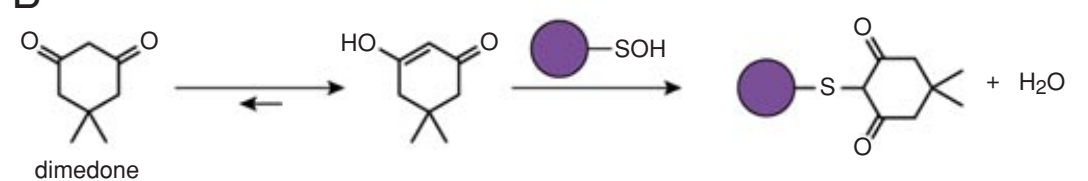
dimedone

C
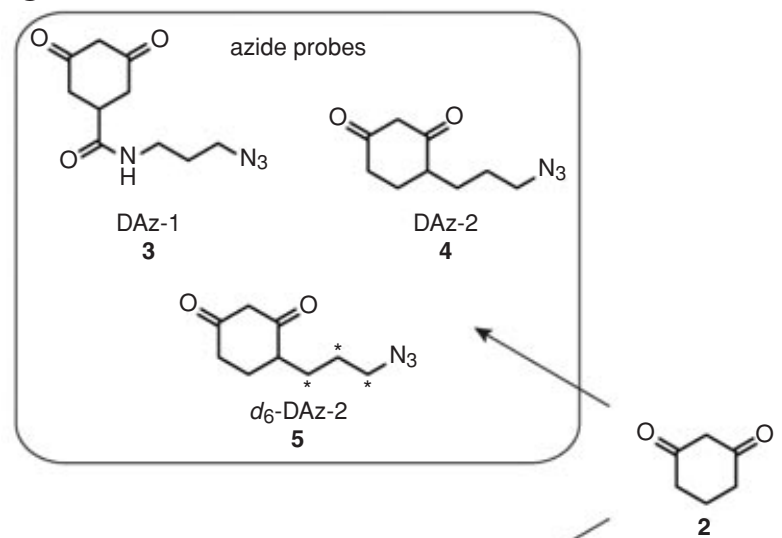

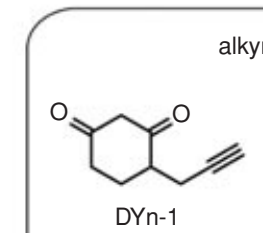
lkyne probes<smiles>C#CCCCC1CCC(=O)CC1=O</smiles>

7

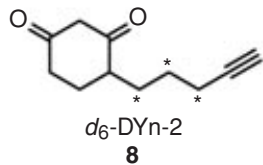

8

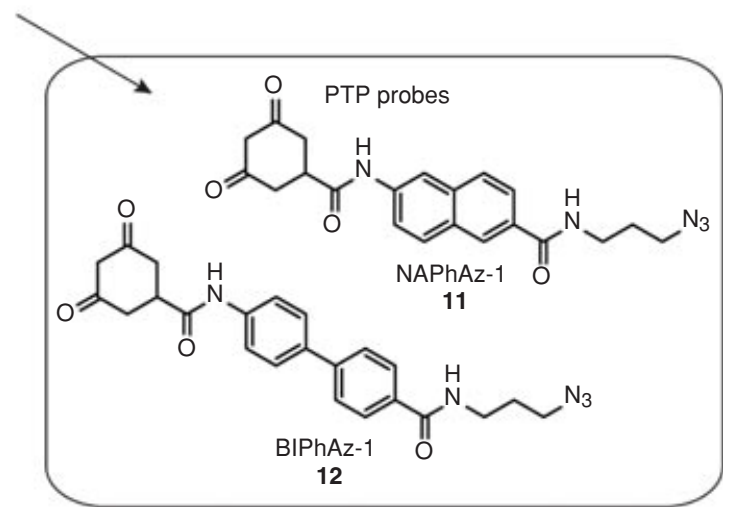

Figure 1 Bioorthogonal detection of protein cysteine oxidation. (A) Oxidative modifications of protein cysteines. Low $p K_{a}$ thiols susceptible to oxidation can react with $\mathrm{H}_{2} \mathrm{O}_{2}$ to form a sulfenic acid, also known as sulfenylation. This modification may be stabilized by the protein microenvironment or condense with a second thiol to form an intra- or inter-molecular disulfide. Alternatively, the sulfenic acid can undergo further oxidation to the sulfinic or sulfonic acid under conditions of high oxidative stress, typically associated with disease states. (B) Chemoselective reaction between sulfenic acid and 5,5-dimethyl-1,3-cyclohexanedione (dimedone, 1). (C) Selective probes for detecting protein sulfenic acids based on the 1,3-cyclohexanedione scaffold (2). These probes are functionalized with azide (3-5) or alkyne (6-8) chemical reporter groups, allow for relative quantification of sulfenic acids (9-10), and can target specific classes of redox-regulated proteins, such as protein tyrosine phosphatases (PTPs) (11-12).

Bioorthogonal

Reporters for

Protein

Sulfenylation

\section{3}


intracellular signaling networks in physiology and disease. Furthermore, the exploitation of redox-modulating strategies for cancer therapy requires a detailed understanding of the structure-activity relationships of sulfenyl modifications and their roles in complex biological processes.

\section{STRATEGIC PLANNING}

\section{Labeling Sulfenylated Proteins In Vitro}

In Basic Protocol 1, the in vitro labeling method for a purified protein is demonstrated using the commercially available enzyme glyceraldehyde 3-phosphate dehydrogenase (GADPH). Upon exposure to $\mathrm{H}_{2} \mathrm{O}_{2}$, GAPDH becomes sulfenylated at the active-site cysteine (C149) (Benitez and Allison, 1974) and the modification is readily detected by the probes (Leonard et al., 2009; Seo and Carroll, 2009). This method can also be applied to investigate oxidation in other proteins that harbor $\mathrm{H}_{2} \mathrm{O}_{2}$-sensitive cysteine residues. The experimental parameters for oxidation and protein labeling described in Basic Protocol 1 have been optimized for GAPDH. Nevertheless, depending on the properties of the protein under study, it may be necessary to adjust some of the conditions if the reported procedure does not yield satisfactory results. For example, the $\mathrm{H}_{2} \mathrm{O}_{2}$ dose and exposure time can be adjusted to modulate the extent of cysteine oxidation. Similarly, probe concentration or labeling time can be changed to optimize the signal-to-noise ratio. For reference, the reaction rate of dimedone-based probes with protein sulfenic acids is on the order of $10^{3} \mathrm{M}^{-1} \mathrm{~min}^{-1}$ (Poole et al., 2007). It is recommended that the user first attempt the conditions outlined in Basic Protocol 1 with the protein of interest prior to adjusting any experimental conditions. If the candidate protein demonstrates $\mathrm{H}_{2} \mathrm{O}_{2}$ sensitivity, downstream experiments may involve site-directed mutagenesis of the target cysteine and/or mass spectrometry (MS) analysis of intact and digested protein after probe labeling to map the site(s) of modification. In particular, the authors' laboratory has demonstrated this with respect to wild-type and C36S Gpx3 with DAz-1 (Paulsen and Carroll, 2009) and with isotope-coded probe pairs (Seo and Carroll, 2011; Truong et al., 2011).

\section{Labeling Sulfenylated Proteins in Living Cells}

An approach for detecting protein sulfenyl modifications in situ for two human cell lines, A431 and HepG2 (Fig. 2A), is presented in Basic Protocol 2. A431 epithelial cells are a rich model for studying the biology of epidermal growth factor receptor (EGFR) signaling and for preclinical evaluation of EGFR therapeutics. The HepG2 epithelial cell line is also a suitable model system for the study of receptor-mediated $\mathrm{H}_{2} \mathrm{O}_{2}$ production and concomitant protein sulfenylation. In Basic Protocol 2, it is demonstrated that EGF stimulation of A431 cells leads to dynamic global changes in protein sulfenylation, which may be important for growth factor signaling. The protocol can be adapted to monitor changes in sulfenylation with other cell lines and stimulants, but the dose- and timedependent effects of a particular stimulant on protein sulfenylation should be evaluated for each new cell line. Likewise, probe concentration and labeling time may require some optimization. In addition, serum starvation of cells may be required to reduce high basal levels of sulfenylation. The procedure outlined in Basic Protocol 2 is somewhat involved and may prove difficult for investigators new to mammalian cell culture. Consequently, in Basic Protocol 3, a scaled-down method is presented for detecting protein sulfenylation in HepG2 cells exposed to exogenous $\mathrm{H}_{2} \mathrm{O}_{2}$. HeLa cells may also be used in Basic Protocol 3, as they are another robust cell line that is easily propagated in the laboratory. Basic Protocols 2 and 3 call for the preparation of a single cell suspension from adherent culture for probe labeling, so it is prudent to work efficiently and avoid significant time delay after stimulation. As labeling in suspension may not prove ideal for some cell lines or stimulants, alternative methods are provided for labeling cells that remain attached to the plate in Alternate Protocols 1 and 2. 


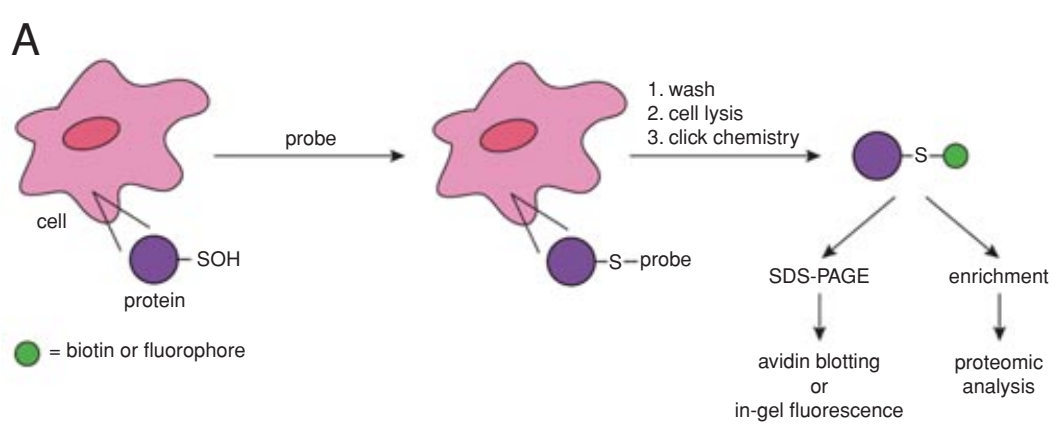

B

$\mathrm{O} \equiv+\mathrm{N}_{3} \longrightarrow \stackrel{\mathrm{TCEP}, \mathrm{CB} \text { TA }}{\longrightarrow}$

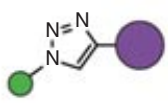

$\mathrm{N}_{3}-\equiv \bigcirc \stackrel{\substack{\mathrm{Cu}^{\mathrm{I}} \\ \text { TCEP, TBTA }}}{\longrightarrow}$

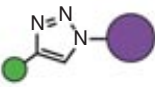

$\mathrm{C}$
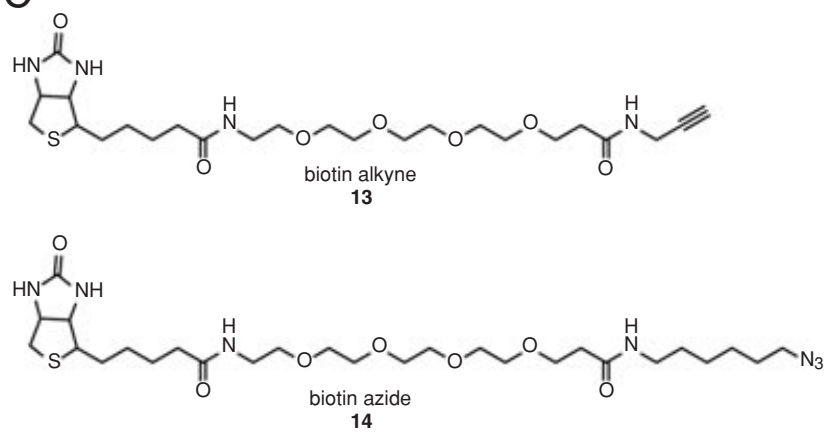

$\mathrm{D}$
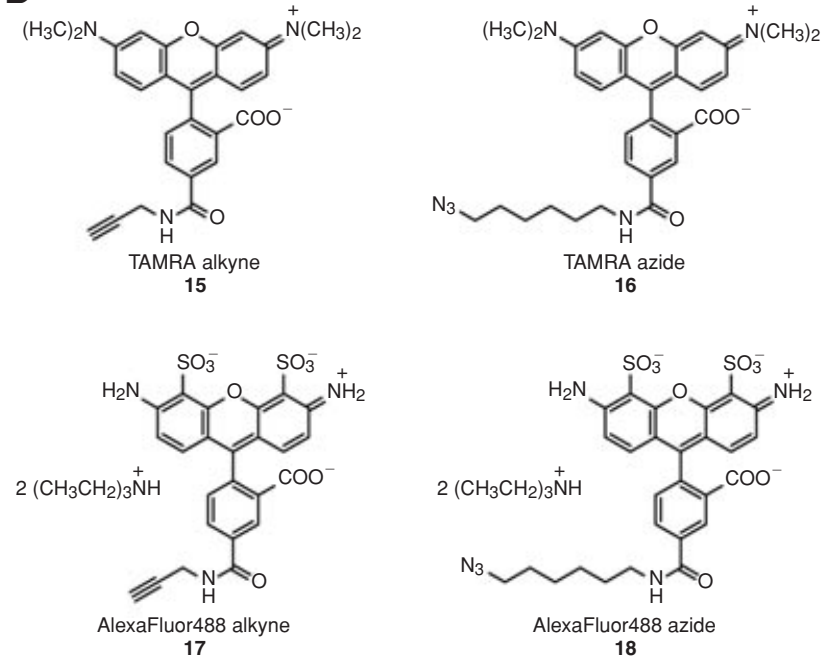

Figure 2 Cell-based detection of protein sulfenylation. (A) Strategy to detect protein sulfenylation in living cells. Sulfenic acids are labeled in situ using selective, cell-permeable chemical probes. Cells are then washed, homogenized, and probe-labeled proteins are conjugated to a biotin or fluorescent tag via the bioorthogonal click chemistry reaction. This approach enables downstream detection by immunoblot or in-gel fluorescence. Alternatively, biotinylated proteins may be enriched for proteomic analysis. (B) Generic scheme for click chemistry bioconjugation. (C) Biotin tags utilized in this study. (D) Fluorescent tags utilized in this study.

Bioorthogonal

Reporters for

Protein

Sulfenylation

\section{5}

Volume 4 


\section{Choice of Chemical Reporter for Analyzing Protein Sulfenylation}

DAz-2 and DYn-2 (4 and 7; Fig. 1C) can both be used to detect protein sulfenylation directly in cells. The major difference between these two probes is the identity of the chemical reporter group (azide or alkyne), which dictates the orientation of the triazole when "clicked" to the appropriate reporter tag (Fig. 2B). The choice of probe depends on downstream analysis methods. If immunoblot detection is desired, either probe can be utilized with the corresponding biotin reporter tag (13 or 14; Fig. 2C). However, for ingel fluorescent detection, the exclusive use of the DYn-2 probe and azide-functionalized fluorescent tags (16 or 18; Fig. 2D) is recommended owing to the lower background signal reported for this orientation (Charron et al., 2009).

\section{Bioorthogonal Ligation of Reporter-Labeled Proteins}

Once proteins are labeled with DAz-2 or DYn-2, they can be detected via bioorthogonal ligation with a biotin or fluorescent tag (Fig. 2B). In the protocol, click chemistry is described as the main method of bioorthogonal ligation. The utility of click chemistry in vitro and in cells has been demonstrated by the authors and others (Speers et al., 2003; Paulsen et al., 2011; Truong et al., 2011; Wilson et al., 2011). It is also possible to detect azide-tagged proteins through Staudinger ligation with various phosphine-based reactive partners (Reddie et al., 2008; Leonard et al., 2009), although this approach is not included here.

\section{Additional Considerations and Controls}

For labeling sulfenylated proteins in vitro or in live cells, it is important to consider factors that can influence basal levels of cysteine oxidation. For example, reactive cysteines in recombinant proteins can undergo oxidation in the presence of oxygen and trace amounts of transition metal ions in phosphate or Tris-based buffer solutions. If this presents an issue for the user, buffer solutions can be made anaerobic by purging with nitrogen. In addition, cells should be cultured carefully (i.e., regular schedule for splitting, appropriate plating density, no more than 20 passages, mycoplasma testing) in high-quality medium. Poor culturing conditions can lead to cell stress and higher basal levels of cysteine oxidation. It is also recommended that the user occasionally monitor cellular ROS levels by using carboxy- $\mathrm{H}_{2}$ DCFDA (Invitrogen) and/or a general protein marker for oxidative stress, such as an antibody against the hyper-oxidized form of peroxiredoxin $\left(\operatorname{Prx}-\mathrm{SO}_{3}\right.$, Abcam). Furthermore, analogous to phosphorylation studies, serum starvation may be required to reduce high basal levels of protein sulfenylation. Lastly, control reactions should always be performed in the absence of chemical probe, as indicated in each section below.

BASIC PROTOCOL 1

Bioorthogonal Reporters for Protein Sulfenylation

\section{LABELING SULFENYLATED PROTEINS IN VITRO}

The following is a standard protocol for in vitro labeling of sulfenyl modifications in purified proteins. GAPDH is used as the model system here because it is well known to undergo sulfenylation at its active-site cysteine (C149). This protocol can be applied to investigate sulfenylation in any other protein of interest. Proteins can be labeled with a number of biotin or fluorescent chemical reporters, allowing for immunoblot or in-gel fluorescent detection of labeled proteins.

\section{Materials}

GAPDH, lyophilized powder (Sigma-Aldrich) or other purified protein of interest Tris labeling buffer (see recipe)

$50 \mathrm{mM}$ tris(2-carboxyethyl) phosphine hydrochloride (TCEP; Sigma-Aldrich), prepared fresh in water 
Bio-Spin 6 columns, pre-packed in Tris buffer (BioRad)

DMSO (vehicle; Sigma-Aldrich)

25 mM DAz-2 (Cayman Chemicals) or DYn-2 (Cayman Chemicals), prepared in DMSO

$1 \mathrm{mM} \mathrm{H}_{2} \mathrm{O}_{2}$ stock (Sigma-Aldrich), prepared fresh in water and maintained on ice

Click labeling buffer (see recipe)

$5 \mathrm{mM}$ biotin tag (biotin alkyne or azide; Invitrogen) in DMSO or $5 \mathrm{mM}$ fluorescent tag (TAMRA or AlexaFluor488 azide; Invitrogen) in DMSO

$2 \mathrm{mM}$ tris[(1-benzyl-1H-1,2,3-triazol-4-yl)methyl] amine (TBTA; Sigma Aldrich), prepared in 4:1 DMSO/t-butanol (TBTA can also be synthesized by published methods; Chan et al., 2004)

$50 \mathrm{mM} \mathrm{CuSO}_{4}$, prepared fresh in water

$1 \times$ PBS (Boston BioProducts)

$2 \times$ Laemmli sample buffer with $10 \% \beta$-mercaptoethanol (BioRad)

Mini-Protean TGX 4\% to 15\% Tris-Glycine protein gels (BioRad)

Centrifuge

NanoDrop2000c spectrophotometer (Thermo Scientific)

$37^{\circ} \mathrm{C}$ incubator with shaker

Platform shaker

$95^{\circ} \mathrm{C}$ heating block

1. Resuspend GAPDH to $4 \mathrm{mg} / \mathrm{ml}$ in Tris labeling buffer.

GAPDH at $4 \mathrm{mg} / \mathrm{ml}$ is recommended to obtain a starting concentration of $\sim 110 \mu \mathrm{M}$. If using a different protein, the protein of interest should have a starting concentration of $\sim 100$ to $110 \mu \mathrm{M}$. The relatively high protein concentration facilitates downstream gelbased MS analysis. However, if this is not desired, lower initial protein concentrations may also be used.

2. Reduce GAPDH with $1 \mathrm{mM}$ TCEP for $30 \mathrm{~min}$ at room temperature.

A freshly prepared stock solution of $50 \mathrm{mM}$ TCEP should be used to obtain a final concentration of $1 \mathrm{mM}$ TCEP for reduction of protein thiols.

3. After protein reduction, remove excess TCEP with Bio-Spin 6 columns (preequilibrated with Tris labeling buffer). Load $100 \mu \mathrm{l}$ GAPDH protein per column. To collect the reduced GAPDH protein, centrifuge columns 4 min at $1000 \times g$, room temperature.

The Bio-Spin 6 columns must be pre-equilibrated with the appropriate buffer prior to use. To achieve this, centrifuge columns for 2 min at $1000 \times g$ to remove packing buffer. Apply the new Tris labeling buffer in 500- $\mu$ l aliquots. After each application of new buffer, centrifuge the column for 1 min at $1000 \times g$. Repeat as required. The authors perform four washes, which results in $>99.9 \%$ of buffer exchanged.

4. Determine GAPDH protein concentration using a NanoDrop2000c spectrophotometer and a molar extinction coefficient of $\varepsilon_{280}=32,890 \mathrm{M}^{-1} \mathrm{~cm}^{-1}$.

5. Label $25 \mu \mathrm{M}$ GAPDH with $1 \mathrm{mM} \mathrm{DAz}-2$ or DYn-2 (from $25 \mathrm{mM}$ probe stock) by incubating GAPDH with 1.5 eq. $\mathrm{H}_{2} \mathrm{O}_{2}\left(37.5 \mu \mathrm{M}\right.$ from $1 \mathrm{mM} \mathrm{H}_{2} \mathrm{O}_{2}$ stock) or $\mathrm{H}_{2} \mathrm{O}$ (mock treatment). In addition, prepare a no-probe control. Add reaction components to make up a total volume of $100 \mu \mathrm{l}$ in the following order:

\section{GAPDH}

Tris labeling buffer (to make up remaining reaction volume)

$3.75 \mu \mathrm{l} 1 \mathrm{mM} \mathrm{H}_{2} \mathrm{O}_{2}$ (final concentration of $37.5 \mu \mathrm{M}$ )

$4 \mu \mathrm{l} 25 \mathrm{mM}$ DAz-2 or DYn-2 (final concentration of $1 \mathrm{mM}$ )

6. Rock labeling reactions for $1 \mathrm{hr}$ at $37^{\circ} \mathrm{C}$.

Bioorthogonal

Reporters for

Protein

Sulfenylation

107

Current Protocols in Chemical Biology

Volume 4 
7. After protein labeling, remove excess probe with Bio-Spin 6 columns (preequilibrated with click labeling buffer) by loading $95 \mu$ labeling reaction per column. To collect the labeled GAPDH protein, centrifuge columns for $4 \mathrm{~min}$ at $1000 \times g$, room temperature.

8. Detect probe-labeled proteins by orthogonal click chemistry by adding the reaction components in the following order to each sample and mix well (total volume of the click chemistry reaction should be $100 \mu \mathrm{l})$ :

$2 \mu 15 \mathrm{mM}$ biotin or fluorescent reporter tag (final concentration $100 \mu \mathrm{M}$ )

$2 \mu \mathrm{l} 50 \mathrm{mM}$ TCEP (final concentration $1 \mathrm{mM}$ )

$5 \mu \mathrm{l} 2 \mathrm{mM}$ TBTA (final concentration of $100 \mu \mathrm{M}$ )

$2 \mu \mathrm{l} 50 \mathrm{mM} \mathrm{CuSO}_{4}$ (final concentration of $1 \mathrm{mM}$ )

9. Rock click chemistry reactions for $1 \mathrm{hr}$ at room temperature.

If a fluorescent reporter tag is being used (i.e., TAMRA or AlexaFluor488 azide), perform reactions in the dark. In addition, take all necessary precautions to carry out remaining steps in the dark if a fluorescent tag is used.

10. After click chemistry, remove excess reagents with Bio-Spin 6 columns (preequilibrated with PBS) by loading $95 \mu \mathrm{l}$ labeling reaction per column. To collect the labeled GAPDH protein, centrifuge columns 4 min at $1000 \times g$, room temperature.

11. Add $100 \mu \mathrm{l}$ of $2 \times$ Laemmli sample buffer $(10 \% \beta-\mathrm{ME})$ to each column eluate.

Note that the expected recovery of GADPH applied to a Bio-Spin 6 column is $\sim 80 \%$. This parameter must be empirically determined if a protein other than GAPDH is used.

12. Boil protein samples $10 \mathrm{~min}$ in a $95^{\circ} \mathrm{C}$ heating block.

13. Resolve samples by SDS-PAGE using Mini-Protean TGX 4\% to 15\% Tris-Glycine gels.

For GADPH, 200 ng protein per lane is typically loaded.

14. Analyze results with one of the following detection methods of choice.

a. Detect by immunoblotting (see Basic Protocol 4; Fig. 3A, DAz-2/biotin alkyne; Fig. 3B, DYn-2/biotin azide).

b. Detect by in-gel fluorescence (see Basic Protocol 5; Fig. 3C, DYn-2/TAMRA azide; Fig. 3D, DYn-2/AlexaFluor488 azide).

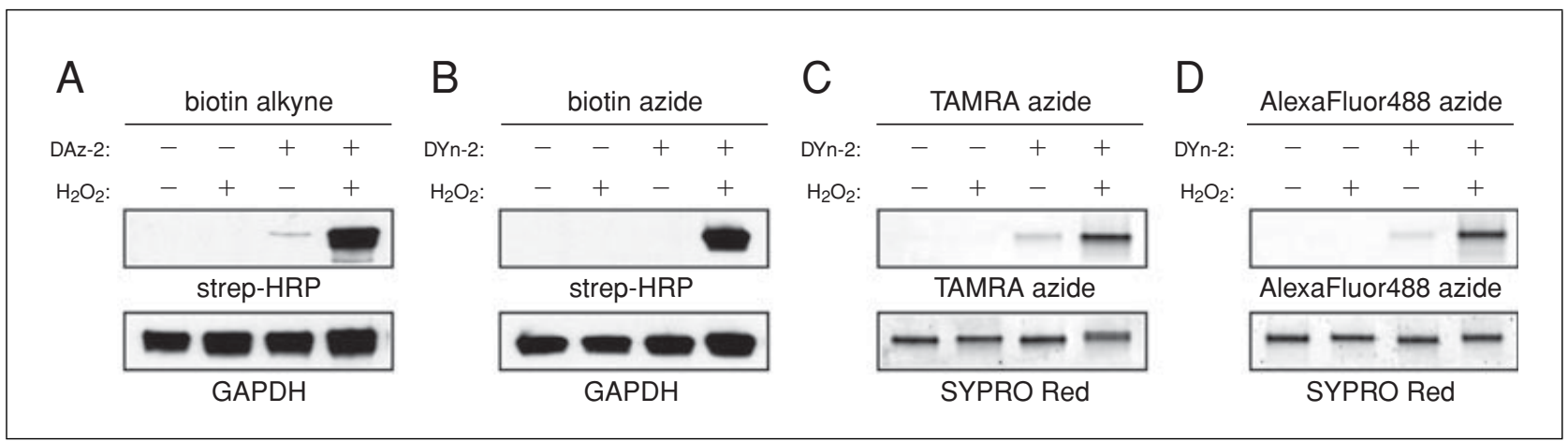

Figure 3 Detection of sulfenyl modifications with purified protein in vitro. GAPDH was stimulated with $\mathrm{H}_{2} \mathrm{O}_{2}$ and labeled with DAz-2 or DYn-2 for $1 \mathrm{hr}$. Probe-labeled GAPDH can be detected by streptavidin-HRP immunoblot (A-B) or ingel fluorescence (C-D). Equal protein loading is demonstrated by reprobing the immunoblot with antibodies to GAPDH (immunoblot) or by SYPRO red dye staining of the SDS-PAGE gel (fluorescence). 


\section{LABELING ENDOGENOUS SULFENYLATED PROTEINS IN CELL SUSPENSION}

The following is the standard protocol for labeling intact A431 cells in suspension. It has been recently demonstrated that $\mathrm{A} 431$ cells produce $\mathrm{H}_{2} \mathrm{O}_{2}$ upon stimulation with EGF, which leads to dynamic global changes in protein sulfenylation (Paulsen et al., 2011). In these experiments, the EGFR kinase is activated in A431 cells by stimulation with EGF ligand. It is recommended to examine other cell lines and stimulants as appropriate in specific experiments. It is also recommended that the user consider starting with Basic Protocol 3 to gain basic proficiency in these techniques prior to attempting the more involved system described in this protocol. Labeled proteins can be detected by immunoblot or in-gel fluorescence.

\section{Materials}

A431 cells (ATCC)

DMEM complete culture medium (high-glucose DMEM supplemented with $10 \%$

FBS, 1\% GlutaMax, 1\% MEM nonessential amino acids, and 1\% penicillin-streptomycin; Invitrogen)

$1 \times$ PBS (Boston BioProducts)

DMEM only (serum-free, high-glucose DMEM; Invitrogen)

$30 \mu \mathrm{g} / \mathrm{ml}$ EGF stock (BD Biosciences), prepared in $\mathrm{H}_{2} \mathrm{O}$ and kept on ice

$0.25 \%$ trypsin (Invitrogen)

250 mM DAz-2 (Cayman Chemicals) or DYn-2 (Cayman Chemicals), prepared in DMSO

DMSO (vehicle; Sigma-Aldrich)

Modified RIPA lysis buffer supplemented with EDTA-free protease inhibitors and $200 \mathrm{U} / \mathrm{ml}$ catalase (see recipe)

BCA protein assay (Pierce)

$5 \mathrm{mM}$ biotin tag (biotin alkyne or azide; Invitrogen) in DMSO or $5 \mathrm{mM}$ fluorescent tag (TAMRA or AlexaFluor488 azide; Invitrogen) in DMSO

$50 \mathrm{mM}$ TCEP (Sigma-Aldrich), prepared fresh in water

$2 \mathrm{mM}$ TBTA (Sigma Aldrich), prepared in 4:1 DMSO/t-butanol (TBTA also

synthesized by published methods; Chan et al., 2004)

$50 \mathrm{mM} \mathrm{CuSO}_{4}$, prepared fresh in water

0.5 M EDTA (Boston BioProducts)

$10 \%$ SDS, prepared in $\mathrm{H}_{2} \mathrm{O}$

$2 \times$ Laemmli sample buffer with $10 \% \beta$-mercaptoethanol (BioRad)

Mini-Protean TGX 4\% to 15\% Tris-Glycine protein gels (BioRad)

$37^{\circ} \mathrm{C}$ incubator

Refrigerated centrifuge

1.5 -ml microcentrifuge tubes

$95^{\circ} \mathrm{C}$ heating block

Vortex

1. Grow A431 cells to $75 \%$ to $80 \%$ confluency in DMEM complete culture medium at $37^{\circ} \mathrm{C}$.

All volumes used in the remainder of this protocol are reported with respect to 100-mm dishes.

2. Remove the DMEM complete culture medium, wash plates quickly three times with enough PBS to cover cells, and incubate cells in $10 \mathrm{ml}$ serum-free DMEM for $16 \mathrm{hr}$ at $37^{\circ} \mathrm{C}$.

Culture medium and other cell culture reagents (e.g., 0.25\% trypsin) should always be pre-warmed to $37^{\circ} \mathrm{C}$ prior to use in an experiment. Cells are very sensitive to changes
Bioorthogonal

Reporters for

Protein

Sulfenylation

\section{9}

Volume 4 
in temperature and all precautions should be taken to avoid sudden alterations in the culture environment.

3. After serum starvation, remove serum-free DMEM and wash plates three times with PBS.

4. Add $5 \mathrm{ml}$ serum-free DMEM containing $100 \mathrm{ng} / \mathrm{ml}$ EGF to each plate of cells and stimulate for $5 \mathrm{~min}$ at $37^{\circ} \mathrm{C}$.

A control should be performed in parallel using un-stimulated cells to assess EGFdependent changes in protein sulfenylation.

5. At the end of the incubation period, remove the stimulation medium and wash plates three times with PBS.

6. Lift cells with $0.25 \%$ trypsin. Add $5 \mathrm{ml}$ of serum-free DMEM to quench trypsin, and collect cells by centrifuging $2 \mathrm{~min}$ at $1500 \times \mathrm{g}$, room temperature.

7. Remove medium and resuspend cells in serum-free DMEM at a density of $3-4 \times$ $10^{6}$ cells $/ \mathrm{ml}$.

One 100-mm plate of A431 cells will typically yield $\sim 3 \times 10^{6}$ cells. Accordingly, each plate is resuspended in $800 \mu \mathrm{l}$ serum-free DMEM, and 400- $\mu \mathrm{l}$ aliquots of cell suspension are transferred to 1.5-ml microcentrifuge tubes for labeling experiments.

8. Label cells with $5 \mathrm{mM} \mathrm{DAz}-2$ or DYn-2 (from $250 \mathrm{mM}$ probe stock). To $400 \mu \mathrm{l}$ of cell suspension sample, add $8.2 \mu \mathrm{l}$ DAz-2 or DYn-2 and gently mix. Use DMSO as a concurrent vehicle control for all probe-labeling experiments.

9. Incubate cell labeling reactions for $1 \mathrm{hr}$ at $37^{\circ} \mathrm{C}$.

After 30 min, gently mix cells. Labeling times may range from 15 min to $2 \mathrm{hr}$. This variable is cell- and stimulant-type dependent.

10. After cell labeling, remove excess probe by washing cells three times, each time with $500 \mu \mathrm{lBS}$, and centrifuging $2 \mathrm{~min}$ at $1500 \times \mathrm{g}$, room temperature.

At this point, washed cell pellets can be frozen in liquid $N_{2}$ and stored at $-80^{\circ} \mathrm{C}$. Otherwise, it is recommended to proceed with the experiment up to the precipitation step.

11. Lyse cells in modified RIPA lysis buffer for $20 \mathrm{~min}$ on ice.

Cell lysis can be aided by vortexing or pipetting up and down.

12. Clear lysate of cell debris by centrifuging $20 \mathrm{~min}$ at $16,000 \times g, 4^{\circ} \mathrm{C}$.

13. Quantify protein content of cleared cell lysate using a standard BCA assay.

Protein concentrations typically range from 2 to $8 \mathrm{mg} / \mathrm{ml}$, depending on the cell type.

14. If a biotin tag is used to detect labeled proteins by immunoblot, perform a preclear step to remove endogenous biotinylated proteins prior to click chemistry (see Support Protocol 1). If a fluorescent tag is used to detect labeled proteins by in-gel fluorescence, omit the pre-clear step and continue to the next step.

15. Transfer $100 \mu \mathrm{g}$ cell lysate to $1.5-\mathrm{ml}$ microcentrifuge tubes for each sample.

16. Detect probe-labeled proteins via click chemistry by adding the reaction components in the following order to each sample and mixing well (the total volume of the click chemistry reaction should be $100 \mu \mathrm{l})$ :

$89 \mu \mathrm{l}$ cell lysate $(100 \mu \mathrm{g})$

$2 \mu \mathrm{l} 5 \mathrm{mM}$ biotin or fluorescent reporter tag (final concentration $100 \mu \mathrm{M}$ )

$2 \mu \mathrm{l} 50 \mathrm{mM}$ TCEP (final concentration $1 \mathrm{mM}$ ) 
$5 \mu \mathrm{l} 2 \mathrm{mM}$ TBTA (final concentration $100 \mu \mathrm{M}$ )

$2 \mu \mathrm{l} 50 \mathrm{mM} \mathrm{CuSO}_{4}$ (final concentration $1 \mathrm{mM}$ )

Make up any remaining volume with the modified RIPA lysis buffer.

17. Rock click chemistry reactions $1 \mathrm{hr}$ at room temperature.

If a fluorescent tag is used (i.e., TAMRA or AlexaFluor488 azide), perform reactions in the dark. In addition, take all necessary precautions to carry out the remaining steps of the experiment in the dark if a fluorescent reagent is used.

18. Quench click chemistry reactions with $40 \mathrm{mM}$ EDTA (from $0.5 \mathrm{M}$ stock). Rock reactions $5 \mathrm{~min}$ at room temperature.

EDTA chelates any remaining copper, thereby quenching the click chemistry reaction.

19. Perform a methanol precipitation (see Support Protocol 2) or methanol/chloroform precipitation (see Support Protocol 3) of the protein.

Either precipitation method works well and the choice is dictated by user preference.

20. Add $20 \mu \mathrm{l}$ of $10 \%$ SDS to dissolve protein pellets.

A bath sonicator may be used at this step to help re-solubilize the protein pellets.

21. Add $20 \mu \mathrm{l}$ of $2 \times$ Laemmli sample buffer $(10 \% \beta-\mathrm{ME})$ to each sample and mix well.

22. Boil protein samples $10 \mathrm{~min}$ using a $95^{\circ} \mathrm{C}$ heating block.

23. Vortex samples and centrifuge $1 \mathrm{~min}$ at $16,000 \times g$, room temperature.

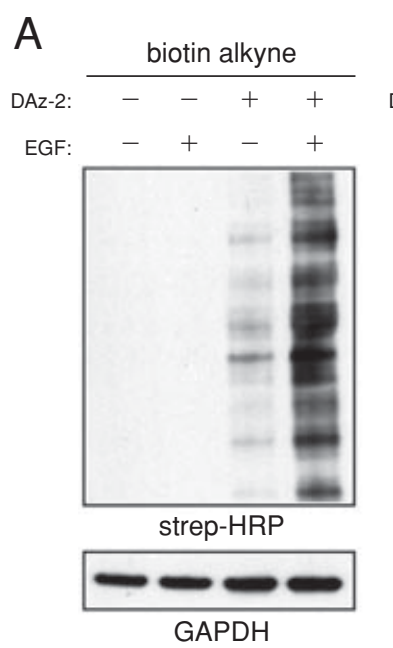

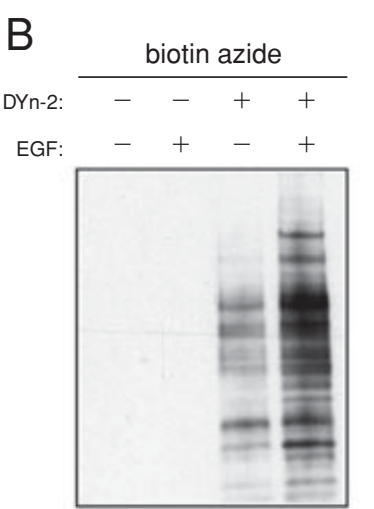

strep-HRP

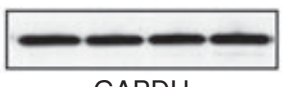

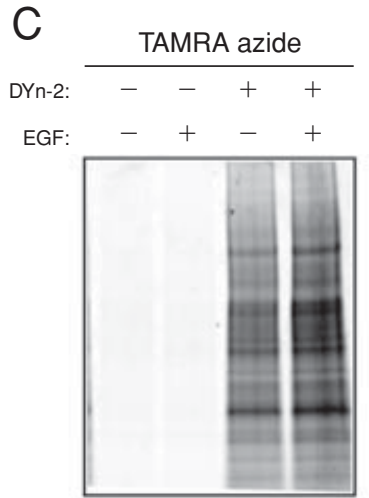

TAMRA azide

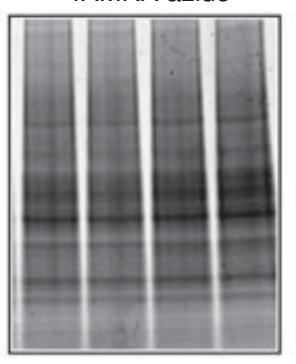

SYPRO Red

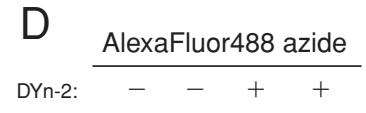

EGF:

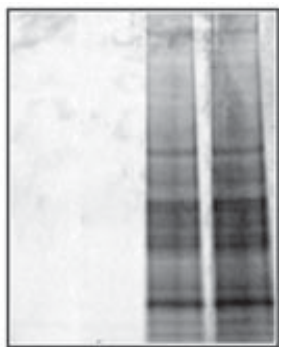

AlexaFluor488 azide

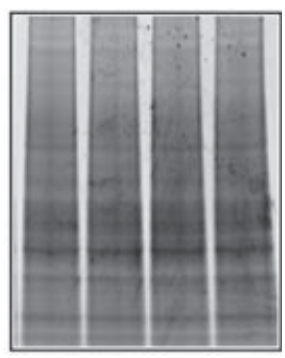

SYPRO Red

Figure 4 Detection of EGF-mediated protein sulfenylation in A431 cells. A431 cells were stimulated with $100 \mathrm{ng} / \mathrm{ml}$ EGF for 5 min. EGFR activation leads to the production of endogenous $\mathrm{H}_{2} \mathrm{O}_{2}$ and concomitant changes in protein sulfenylation. Cells were labeled with DAz-2 or DYn-2 for $1 \mathrm{hr}$. Sulfenylated proteins can be detected by streptavidin-HRP immunoblot (A-B) or in-gel fluorescence (C-D). Equal protein loading is demonstrated by reprobing the immunoblot with antibodies to GAPDH (immunoblot) or by SYPRO red dye staining of the SDS-PAGE gel (fluorescence). 
24. Resolve samples by SDS-PAGE using Mini-Protean TGX 4\% to $15 \%$ Tris-Glycine gels.

Typically, $25 \mu \mathrm{g}$ protein/lane is adequate to detect protein sulfenylation.

25. Analyze experimental results with one of the following detection methods:

a. Immunoblotting (see Basic Protocol 4; Fig. 4A: DAz-2/biotin alkyne; Fig. 4B: DYn2/biotin azide)

b. In-gel fluorescence (see Basic Protocol 5; Fig. 4C: DYn-2/TAMRA azide; Fig. 4D: DYn-2/AlexaFluor488 azide)

BASIC PROTOCOL 3
Bioorthogonal Reporters for Protein Sulfenylation

\section{LABELING EXOGENOUS SULFENYLATED PROTEINS IN CELL SUSPENSION}

The following is a standard protocol for live-cell labeling of sulfenyl modifications in HepG2 cells, which are easy to subculture and manipulate. In this protocol, exogenous $\mathrm{H}_{2} \mathrm{O}_{2}$ is applied directly to cells, as opposed to ligand stimulation of endogenous $\mathrm{H}_{2} \mathrm{O}_{2}$ production. HeLa cells can be substituted for HepG 2 cells in these experiments (Leonard et al., 2009).

\section{Materials}

\section{HepG2 cells (ATCC)}

MEM complete culture medium (MEM supplemented with $10 \%$ FBS, $1 \%$

GlutaMax, $1 \%$ MEM nonessential amino acids, and 1\% penicillin-streptomycin; Invitrogen)

$1 \times$ PBS (Boston BioProducts)

MEM with $0.5 \%$ FBS (MEM supplemented with 0.5\% FBS; Invitrogen)

$100 \mathrm{mM} \mathrm{H}_{2} \mathrm{O}_{2}$ stock (Sigma-Aldrich), prepared fresh in water and maintained on ice

Additional reagents and equipment (see Basic Protocol 2)
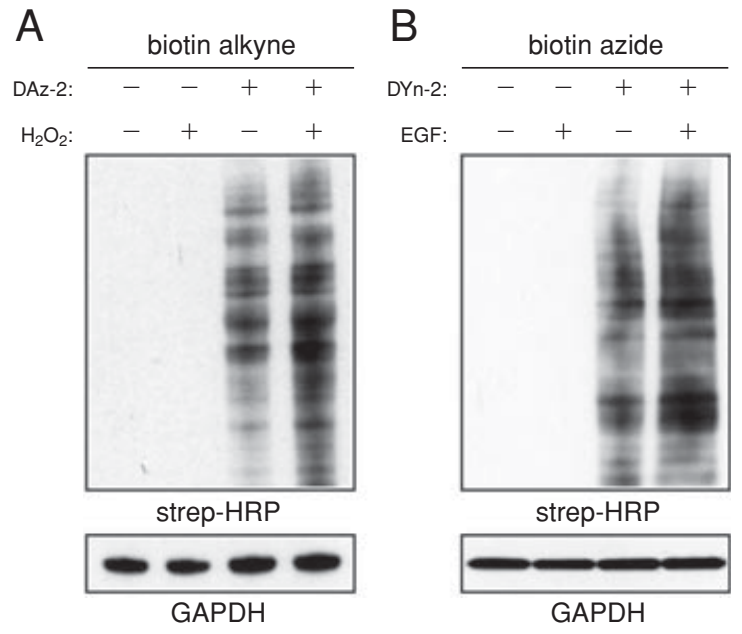

Figure 5 Global changes of protein sulfenylation in HepG2 cells exposed to exogenous $\mathrm{H}_{2} \mathrm{O}_{2}$. HepG2 cells were treated with $500 \mu \mathrm{M} \mathrm{H}_{2} \mathrm{O}_{2}$ for 5 min. Cells were labeled with DAz-2 or DYn-2 for $1 \mathrm{hr}$. Sulfenylated proteins can be detected by streptavidin-HRP immunoblot (A-B) or in-gel fluorescence (not shown). Equal protein loading is demonstrated by reprobing the immunoblot with antibodies to GAPDH (immunoblot). 
1. Grow HepG2 cells to $75 \%$ to $80 \%$ confluency in MEM complete culture medium at $37^{\circ} \mathrm{C}$.

All volumes used in this protocol are reported with respect to 100-mm dishes. Culture medium and other cell culture reagents (e.g., $0.25 \%$ trypsin) should always be pre-warmed to $37^{\circ} \mathrm{C}$ prior to use in an experiment.

2. Remove MEM complete culture medium, and wash plates three times with PBS.

3. Add $5 \mathrm{ml}$ MEM (0.5\% FBS) containing $500 \mu \mathrm{M} \mathrm{H}_{2} \mathrm{O}_{2}$ to each plate. Incubate cells with $\mathrm{H}_{2} \mathrm{O}_{2}$ for 5 min at $37^{\circ} \mathrm{C}$.

A control should be performed in parallel using untreated cells to assess $\mathrm{H}_{2} \mathrm{O}_{2}$-dependent changes in protein sulfenylation.

4. Remove MEM (0.5\% FBS) containing $500 \mu \mathrm{M} \mathrm{H}_{2} \mathrm{O}_{2}$. Wash plates three times with PBS.

5. Proceed with Basic Protocol 2, steps 6 through 25.

For HepG2 cells, take care to use MEM (0.5\% FBS) medium throughout the remainder of the protocol.

Expected results for HepG2 cells can be found in Figure 5A (DAz-2/biotin alkyne) and Figure 5B (DYn-2/biotin azide).

\section{IMMUNOBLOT DETECTION OF BIOTINYLATED PROTEINS}

The following is a standard protocol for immunoblot (western blot) detection of biotinylated proteins. After completing Basic Protocol 1, 2, or 3, the reader should refer to this protocol if a biotin tag (i.e., biotin alkyne or azide) was employed during the click chemistry step.

\section{Materials}

SDS-PAGE gel with resolved samples

PVDF membrane $(0.2-\mu \mathrm{m}$; BioRad)

$3 \%$ BSA (Fisher), prepared in TBST

TBST (Boston BioProducts)

Streptavidin-HRP antibody (GE-Healthcare)

ECL Plus western blot detection system (GE Healthcare)

GAPDH antibody (Santa Cruz Biotechnology)

Rabbit anti-mouse IgG-HRP (Invitrogen)

X-ray film

1. Transfer SDS-PAGE gel with samples of interest onto a PVDF membrane using standard immunoblot transfer techniques (Gallagher et al., 2008).

2. After transfer, block the PVDF membrane with $3 \%$ BSA for $1 \mathrm{hr}$ at room temperature.

3. Wash the membrane two times with TBST for $10 \mathrm{~min}$ at room temperature.

4. Incubate the membrane with streptavidin-HRP $(1: 80,000)$ for $1 \mathrm{hr}$ at room temperature.

All antibodies should be diluted in TBST.

5. After antibody incubation, wash the membrane two times with TBST for $10 \mathrm{~min}$.

6. Develop the membrane with chemiluminescence using the ECL Plus western blot detection system following the manufacturer's instructions.

7. Image results by film.

8. After imaging, re-block the membrane with $3 \% \mathrm{BSA}$ for $1 \mathrm{hr}$ at room temperature.

BASIC

PROTOCOL 4
Bioorthogonal

Reporters for

Protein

Sulfenylation

113 
9. Wash the membrane two times with TBST for $10 \mathrm{~min}$.

10. Incubate the membrane with GADPH primary antibody $(1: 200)$ for $1 \mathrm{hr}$ at room temperature.

GAPDH serves as a loading control. Other protein standards may be used, as necessary.

11. After primary antibody incubation, wash the membrane two times with TBST for $10 \mathrm{~min}$.

12. Incubate the membrane with rabbit anti-mouse $\operatorname{HRP}(1: 50,000)$ for $1 \mathrm{hr}$ at room temperature.

13. After secondary antibody incubation, wash the membrane two times with TBST for $10 \mathrm{~min}$.

14. Develop the membrane with chemiluminescence using the ECL Plus western blot detection system following the manufacturer's instructions.

15. Image results by film.

BASIC PROTOCOL 5
Bioorthogonal Reporters for Protein Sulfenylation

\section{IN-GEL DETECTION OF FLUOROPHORE-TAGGED PROTEINS}

The following is a standard protocol for in-gel detection of fluorophore-tagged proteins. After completing Basic Protocol 1, 2, or 3, the reader should refer to this protocol if a fluorescent tag (i.e., TAMRA or AlexaFluor488 azide) was used during the click chemistry step.

\section{Materials}

SDS-PAGE gel with resolved samples

Destain solution (see recipe)

SYPRO ruby protein stain (BioRad)

Wash solution (see recipe)

Platform rocker

Fluorescence gel scanner (e.g., Amersham Biosciences Typhoon 9400 variable mode imager)

1. Destain SDS-PAGE gel with the samples of interest two times with destain solution for 10 min with rocking.

This step is necessary to remove any background fluorescence from excess reagents. Gels should be handled carefully during all destain and wash steps to avoid background smudging.

2. Wash gel with water for 10 min with rocking.

3. Scan gel using a fluorescence gel scanner.

The authors use a Typhoon 9400 variable mode imager (Amersham Biosciences) for in-gel fluorescence analysis. The fluorescent reagents used in this protocol have the following excitation and emission wavelengths: TAMRA azide, 555/580 nm (ex/em); AlexaFluor488 azide, $495 / 519 \mathrm{~nm}$ (ex/em).

4. After visualizing results from the fluorescent reagent of choice, soak gel in destain solution for $30 \mathrm{~min}$.

5. Stain gel with SYPRO ruby protein stain to demonstrate equal protein loading according to manufacturer's instructions.

The SYPRO ruby signal can typically be seen after a 3-hr incubation. 
6. After staining, wash gel two times with wash solution for $10 \mathrm{~min}$, and one time with water for $10 \mathrm{~min}$ prior to imaging.

SYPRO ruby has the following excitation and emission wavelengths: 280 or $450 / 610 \mathrm{~nm}$ (ex/em).

\section{PRE-CLEARING CELL LYSATES OF ENDOGENOUS BIOTINYLATED PROTEINS}

The following is a standard protocol to pre-clear cell lysates of endogenous biotinylated proteins prior to the click chemistry step.

\section{Materials}

NeutrAvidin agarose resin (Pierce)

Modified RIPA buffer (see recipe)

Cell lysates

1.5-ml microcentrifuge tubes

Centrifuge

Platform rocker at $4{ }^{\circ} \mathrm{C}$

1. Dispense NeutrAvidin resin into 1.5-ml microcentrifuge tubes for each sample.

To pre-clear $100 \mu \mathrm{g}$ cell lysate, use 50 ul of NeutrAvidin resin.

2. Pre-equilibrate NeutrAvidin resin with modified RIPA buffer (three times with 500 $\mu \mathrm{l})$ for $2 \mathrm{~min}$ at $2300 \times g$ at room temperature.

After the last wash, take care to completely remove modified RIPA buffer to maintain consistent protein concentration between each sample.

3. Load $100 \mu \mathrm{g}$ cell lysate onto pre-equilibrated NeutrAvidin resin. Make up any remaining volume with modified RIPA lysis buffer.

The click chemistry reaction is the next step of the protocol, and these reactions should have a total volume of $100 \mu \mathrm{l}$ for $100 \mu \mathrm{g}$ cell lysate (i.e., final protein concentration $=1$ $\mathrm{mg} / \mathrm{ml}$ ). It is important to maintain this volume during the pre-clear step and to consider the subsequent volume of added click chemistry reagents. For example, the volume of the cell lysate loaded onto the NeutrAvidin resin for the pre-clear step should not exceed 89 $\mu l$ for $100 \mu \mathrm{g}$ cell lysate, as the remaining volume $(11 \mu \mathrm{l})$ will be the click chemistry reagents.

4. Rock pre-cleared samples for $30 \mathrm{~min}$ at $4^{\circ} \mathrm{C}$.

5. To collect pre-cleared cell lysate, centrifuge sample $2 \mathrm{~min}$ at $2300 \times \mathrm{g}$, room temperature. Transfer cell lysate to a clean $1.5-\mathrm{ml}$ microcentrifuge tube. Discard NeutrAvidin resin used for the pre-clear step.

The cell lysates are now free of endogenous biotinylated proteins. Continue with Basic Protocol 2 for A431 cells or Basic Protocol 3 for HepG2 cells.

\section{METHANOL PRECIPITATION OF PROTEINS}

The following is a standard protocol for methanol precipitation of proteins after click chemistry. Alternatively, the reader may choose to perform a methanol/chloroform (see Support Protocol 3) precipitation.

\section{Materials}

Click chemistry reaction of cell lysate

Methanol, ice-cold

Refrigerated centrifuge 
1. Add $1 \mathrm{ml}$ ice-cold methanol to each sample and vortex to mix.

2. Allow proteins to precipitate overnight at $-80^{\circ} \mathrm{C}$.

3. Collect protein pellet by centrifuging samples $10 \mathrm{~min}$ at $16,000 \times g, 4^{\circ} \mathrm{C}$.

4. Carefully remove methanol, being careful not to disturb the protein pellet. Wash protein pellet with $1 \mathrm{ml}$ ice-cold methanol.

The second methanol wash is necessary to remove any residual click chemistry reagents.

5. Centrifuge samples $10 \mathrm{~min}$ at $16,000 \times g, 4^{\circ} \mathrm{C}$.

6. Carefully remove the methanol, leaving protein pellet behind.

Ensure all traces of excess methanol are removed prior to continuing a protocol.

SUPPORT PROTOCOL 3
Bioorthogonal Reporters for Protein Sulfenylation

\section{METHANOL/CHLOROFORM PRECIPITATION OF PROTEINS}

The following is a standard protocol for methanol/chloroform precipitation of proteins after click chemistry.

\section{Materials}

Click chemistry reaction of cell lysate

Methanol, ice-cold

Chloroform, ice-cold

Refrigerated centrifuge

1. To perform a methanol/chloroform precipitation, add the following precipitation components in order to each sample, vortexing sample after addition of each component:

$600 \mu \mathrm{l}$ methanol

$150 \mu$ l chloroform

$400 \mu \mathrm{l} \mathrm{H}_{2} \mathrm{O}$

2. Centrifuge samples $10 \mathrm{~min}$ at $16,000 \times g, 4^{\circ} \mathrm{C}$.

3. Carefully remove and discard as much of the upper aqueous layer as possible, without disturbing the interface layer containing the protein precipitate.

A thin interface layer containing the precipitated protein should form between the upper aqueous layer and the lower organic layer.

4. Add $1 \mathrm{ml}$ ice-cold methanol to each sample and vortex to mix.

5. Centrifuge samples $10 \mathrm{~min}$ at $16,000 \times g, 4^{\circ} \mathrm{C}$.

6. Carefully remove methanol, being careful not to disturb the protein pellet. Wash the protein pellet with $1 \mathrm{ml}$ ice-cold methanol.

The second methanol wash is necessary to remove any residual click chemistry reagents.

7. Centrifuge samples $10 \mathrm{~min}$ at $16,000 \times g, 4^{\circ} \mathrm{C}$.

8. Carefully remove methanol, leaving the protein pellet behind. Allow any remaining methanol or chloroform to evaporate by leaving sample tubes open on the bench. Allow protein pellet to air-dry for $30 \mathrm{~min}$ to $1 \mathrm{hr}$ at room temperature.

The dried protein pellet will be thin and have a translucent white color. It is crucial to allow the protein pellet to completely dry prior to proceeding with the remainder of the protocol. If it is not dry, the protein pellet will be extremely difficult to resuspend. 


\section{ON-PLATE LABELING OF ENDOGENOUS PROTEIN SULFENYLATION IN CELLS}

The following is a standard protocol for labeling cells that remain attached to the plate. Although comparable results are typically observed for suspension versus plate detection of sulfenyl modifications (Figs. 4A and 6A), labeling cells in suspension may not prove ideal for some cell lines or stimulants. The reader should determine which labeling method is best for their purposes.

For materials, see Basic Protocol 2

1. Follow Basic Protocol 2, steps 1 through 5.

For on-plate labeling, cells can be grown in 60-mm tissue culture dishes to reduce probe consumption. Media volumes should be adjusted accordingly for smaller culture plates. For example, EGF stimulation should be performed with $2 \mathrm{ml}$ for 60-mm plates, rather than the $5 \mathrm{ml}$ required for 100-mm plates.

2. Add $2 \mathrm{ml}$ serum-free DMEM containing $5 \mathrm{mM} \mathrm{DAz}-2$ or DYn-2 (from $250 \mathrm{mM}$ probe stock) to each plate of cells.

For $2 \mathrm{ml}$ medium, $40.8 \mu \mathrm{l}$ of $250 \mathrm{mM} \mathrm{DAz-2}$ or DYn-2 is needed to achieve a final concentration of $5 \mathrm{mM}$. In addition, a DMSO vehicle control should always be included for unstimulated and EGF-stimulated cells.

3. Label cells for $1 \mathrm{hr}$ at $37^{\circ} \mathrm{C}$.

4. Remove serum-free DMEM containing $5 \mathrm{mM} \mathrm{DAz-2}$ or DYn-2. Wash plates three times with PBS.

5. Lyse cells in modified RIPA lysis buffer using a rubber policeman. Transfer cell lysates to a clean $1.5-\mathrm{ml}$ microcentrifuge tube.

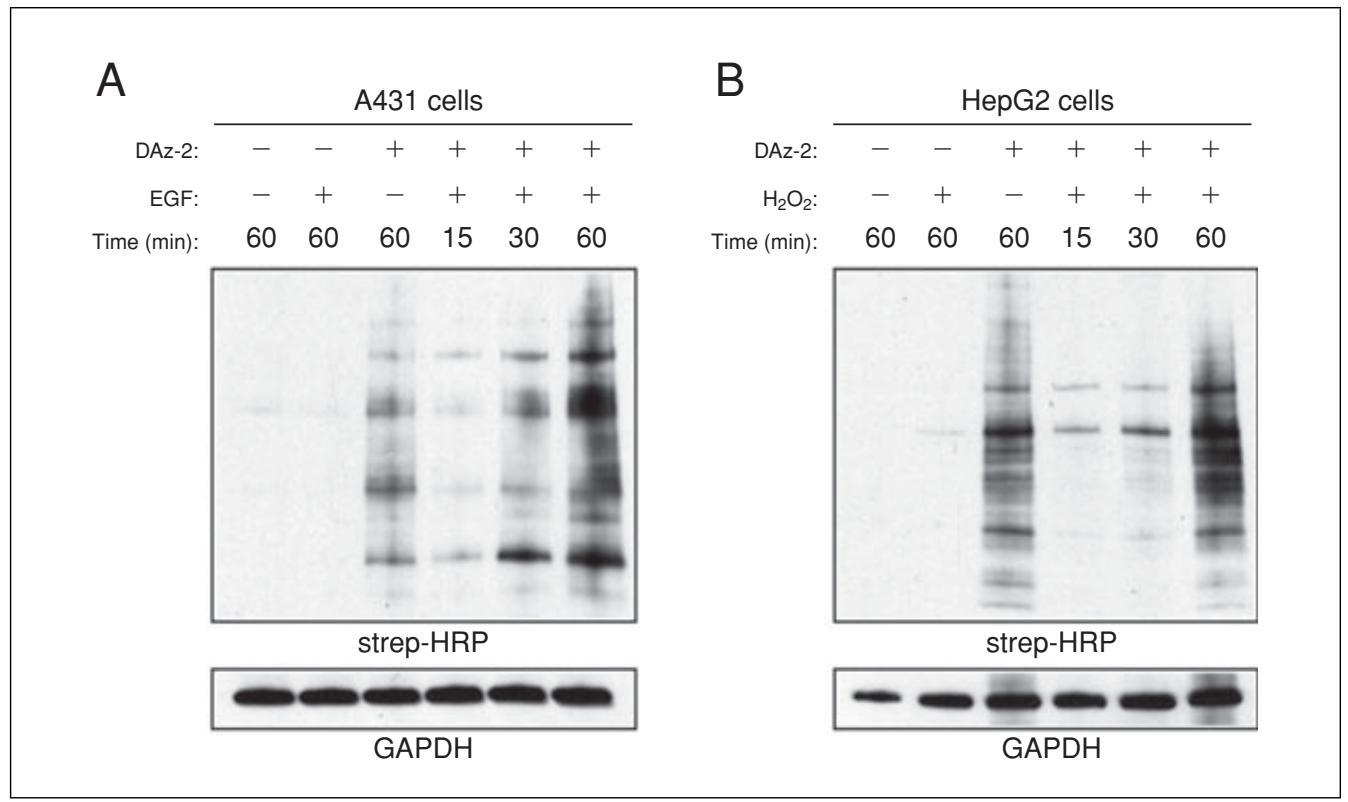

Figure 6 Labeling and detection of protein sulfenylation in adherent A431 and HepG2 cells. Cells were exposed to $100 \mathrm{ng} / \mathrm{ml} \mathrm{EGF} \mathrm{(A431)} \mathrm{or} 500 \mu \mathrm{M} \mathrm{H}_{2} \mathrm{O}_{2}$ (HepG2) for $5 \mathrm{~min}$. After treatment, cells remained attached to the tissue culture plate and were labeled with DAz-2 for the indicated times. Sulfenylated proteins were visualized by streptavidin-HRP immunoblot for (A) A431 cells and (B) HepG2 cells. Equal protein loading is demonstrated by reprobing the immunoblot with antibodies to GAPDH (immunoblot).
Bioorthogonal Reporters for Protein Sulfenylation

\section{7}

Volume 4 
ALTERNATE PROTOCOL 2
6. Proceed with Basic Protocol 2, steps 11 through 25.

Figure 6 A shows representative results for on-plate labeling of protein sulfenyl modifications with DAz-2/biotin alkyne in A431 cells.

Time-dependent labeling of A431 cells that remain attached to the plate indicates that 1-hr labeling yields the best results.

\section{ON-PLATE LABELING OF EXOGENOUS PROTEIN SULFENYLATION IN CELLS}

The following is a standard protocol for on-plate labeling of sulfenylated proteins in HepG2 cells.

For materials, see Basic Protocol 3.

1. Follow Basic Protocol 3, step 1 through 4.

For on-plate labeling, cells can be grown in 60-mm tissue culture dishes to reduce probe consumption. Media volumes should be adjusted accordingly for smaller culture plates. For example, the $\mathrm{H}_{2} \mathrm{O}_{2}$ stimulation should be performed with $2 \mathrm{ml}$ for 60-mm plates, rather than the $5 \mathrm{ml}$ used for 100-mm plates.

2. Add $2 \mathrm{ml}$ MEM (0.5\% FBS) containing $5 \mathrm{mM} \mathrm{DAz-2}$ or DYn-2 (from $250 \mathrm{mM}$ probe stock) to each plate of cells.

For $2 \mathrm{ml}$ medium, $40.8 \mu \mathrm{l}$ of $250 \mathrm{mM} \mathrm{DAz-2}$ or DYn-2 is needed to achieve a final concentration of $5 \mathrm{mM}$. In addition, a DMSO control should always be included for untreated and $\mathrm{H}_{2} \mathrm{O}_{2}$-exposed cells.

3. Label cells for $1 \mathrm{hr}$ at $37^{\circ} \mathrm{C}$.

4. Remove MEM (0.5\% FBS) containing 5 mM DAz-2 or DYn-2. Wash plates three times with PBS.

5. Lyse cells in modified RIPA lysis buffer using a rubber policeman. Transfer cell lysate to a clean $1.5-\mathrm{ml}$ microcentrifuge tube.

6. Proceed with Basic Protocol 2, steps 11 through 25.

Figure $6 B$ depicts representative results for on-plate labeling of HepG2 cells with DAz2/biotin alkyne.

Time-dependent labeling of HepG2 cells that remain attached to the plate indicates that 1 -hr labeling yields the best results.

\section{REAGENTS AND SOLUTIONS}

Use Milli-Q purified water in all recipes and protocol steps.

\section{Click labeling buffer, $\mathrm{pH} 7.4$}

$50 \mathrm{mM}$ triethanolamine, $\mathrm{pH} 7.4$

$1 \%$ SDS

Filter sterilize using a $0.2-\mu \mathrm{m}$ filter

Store up to 6 months at room temperature

\section{Destain solution}

$40 \%$ methanol

$50 \% \mathrm{H}_{2} \mathrm{O}$

$10 \%$ acetic acid

Mix $400 \mathrm{ml}$ methanol, $500 \mathrm{ml} \mathrm{H}_{2} \mathrm{O}$, and $100 \mathrm{ml}$ acetic acid to make 1 liter destain solution. Store up to 1 year at room temperature. 
Modified RIPA lysis buffer, pH 7.4

$50 \mathrm{mM}$ triethanolamine, $\mathrm{pH} 7.4$

$150 \mathrm{mM} \mathrm{NaCl}$

$1 \% \mathrm{NP}-40$

$1 \%$ sodium deoxycholate

$0.1 \%$ SDS

Filter sterilize using a $0.2-\mu \mathrm{m}$ filter

Store up to 1 month at room temperature

Shortly before use, add EDTA-free complete mini protease inhibitors (Roche) according to manufacturer's instructions and $200 \mathrm{U} / \mathrm{ml}$ catalase (Sigma-Aldrich).

\section{Tris labeling buffer, $\mathrm{pH} 7.4$}

$50 \mathrm{mM}$ Tris. $\mathrm{Cl}, \mathrm{pH} 7.4$

$150 \mathrm{mM} \mathrm{NaCl}$

Filter sterilize using a $0.2-\mu \mathrm{m}$ filter

Store up to 6 months at room temperature

\section{Wash solution}

$10 \%$ methanol

$70 \% \mathrm{H}_{2} \mathrm{O}$

$10 \%$ acetic acid

Mix $100 \mathrm{ml}$ methanol, $700 \mathrm{ml} \mathrm{H}_{2} \mathrm{O}$, and $100 \mathrm{ml}$ acetic acid to make 1 liter wash solution. Store up to 1 year at room temperature.

\section{COMMENTARY}

\section{Background Information}

Historically, methods to detect reactive cysteines and $\mathrm{H}_{2} \mathrm{O}_{2}$-mediated oxidation of protein thiols have required the homogenization of cells, which disrupts the native environment. Under these conditions, cellular redox balance and protein structure are compromised, leading to artifactual oxidation during sample processing. This core issue is typically ignored in redox proteomic studies, but casts a pall on the biological significance of such data. To address this problem, small-molecule probes that enable sulfenylated proteins to be trapped and tagged directly in cells have been developed. Using this new approach, the molecular mechanism of $\mathrm{H}_{2} \mathrm{O}_{2}$-sensing in yeast has been dissected (Paulsen and Carroll, 2009), the first in situ proteomic study of protein sulfenylation in mammalian cells has been reported (Leonard et al., 2009), striking differences in sulfenylation profiles among breast cancer subtypes has been uncovered (Seo and Carroll, 2009), a bacterial protein that functions in desulfenylation has been discovered (Depuydt et al., 2009), and sulfenylation functions as a global signaling mechanism akin to phosphorylation during EGFR signaling has been demonstrated (Paulsen et al., 2011). Clearly, selective chemical reporters have opened the door to a better understanding of the important biological role of protein cysteine sulfenylation.

The first global analysis of sulfenylated proteins in HeLa cells revealed that potentially modulatory cysteine residues exist in almost 200 individual proteins, including kinases, phosphatases, transporters, GTPases, and transcription factors, thereby extending this form of redox regulation to a wide range of biological activities (Leonard et al., 2009). Nonetheless, the vast majority of $\mathrm{H}_{2} \mathrm{O}_{2}$-sensitive protein cysteine residues await identification. This is a vigorous area of research in the authors' laboratory and, towards this end, they have developed two complementary isotope-coded probe pairs to quantify changes in protein sulfenylation (9, 10 and 4, 5; Fig. 1C) (Seo and Carroll, 2011; Truong et al., 2011). Most recently, the authors have reported reagents to selectively monitor reversible oxidation of PTPs by adding an active site-targeting module to the sulfenyl probes (10, 11; Fig. 1c) (Leonard et al., 2011).
Bioorthogonal Reporters for Protein Sulfenylation

\section{9}




\section{Critical Parameters and Troubleshooting}

The order in which reagents are added during experiments to purified protein in vitro or cells is an important consideration. In general, the ligand stimulant $\left(\right.$ or $\mathrm{H}_{2} \mathrm{O}_{2}$ ) is added before the probe-labeling step. However, this parameter should be investigated on a case-by-case basis, in addition to dose- and time-dependent changes in labeling.

For cell labeling experiments, cells should be cultured carefully without sudden changes in the culture environment. For example, culture reagents such as media and trypsin should be pre-warmed to $37^{\circ} \mathrm{C}$ prior to use. Depending on the cell line, culture media should be replenished every 2 to 3 days. As with many biological processes studied in a cell culture model, the confluency at the time of stimulation and labeling can impact the final results. If stimulant- or $\mathrm{H}_{2} \mathrm{O}_{2}$-dependent changes in protein sulfenylation are difficult to discern, a number of factors should be examined. All stocks (ligand stimulant and probes) should always be kept on ice during the experiment or otherwise stored at $-30^{\circ} \mathrm{C}$ when not in use. In addition, lysis buffer and cell lysates should be kept on ice at all times. Once cells have been stimulated, subsequent wash and lifting steps should be carried out in a timely manner. Any unnecessary delays in sample handling prior to cell lysis should be avoided, as this may also affect final results. Additionally, for maximum probe potency, culture media used during cell labeling should not exceed $0.5 \%$ FBS.

Click chemistry reactions should always be performed with fresh TCEP and $\mathrm{CuSO}_{4}$ stocks. Typically, these stocks are prepared fresh directly before setting up the reactions. TCEP can oxidize over time, which would reduce the efficiency of the reaction since it is required for reduction of $\mathrm{CuSO}_{4}$ to $\mathrm{Cu}(\mathrm{I})$. In addition, the second methanol wash in both precipitation procedures is crucial to completely remove excess click chemistry reagents. Failure to do so may result in higher background signals during the visualization process. If equal loading is not observed, it is also important to ensure that the protein pellets are completely re-solubilized. In some cases, this can be a challenge, particularly for samples that have been methanol/chloroform precipitated. Protein pellets must be completely free of chloroform prior to re-solubilization, otherwise they will not fully dissolve.

For in-gel fluorescence experiments, special precautions should be taken once the fluorescent tag is added to the sample. Steps such as the click chemistry reaction, SDS-PAGE analysis, and destaining should be performed in the dark to avoid sample bleaching. During SDS-PAGE analysis, the dye front should be run completely off the gel during electrophoresis to remove any unincorporated fluorescent tag and minimize background fluorescence. Gels should also be thoroughly destained and washed prior to imaging. In addition, only clean gloves and containers should be used to handle the gels. Because in-gel fluorescence is an extremely sensitive technique, faulty gel handling can lead to fingerprints and smudges during the visualization process. Gels should only be handled on the edges as carefully as possible with gloved hands, to avoid undesirable blemishes on the scanned image.

\section{Anticipated Results}

Anticipated results for labeling of sulfenic acids in a purified protein (GAPDH) can be found in Figure 3 for both immunoblot (Fig. 3A,B) and in-gel fluorescence detection (Fig. 3C,D). It is expected that the active site cysteine should exhibit a robust $\mathrm{H}_{2} \mathrm{O}_{2-}$ dependent increase in probe labeling. If a peroxide-dependent effect is not observed in the protein of interest, it is possible that the cysteine(s) are not $\mathrm{H}_{2} \mathrm{O}_{2}$-sensitive or that the basal level of oxidation is high. Similarly, anticipated results for labeling of protein sulfenylation in cells (A431) with a stimulant (EGF) that leads to endogenous production of $\mathrm{H}_{2} \mathrm{O}_{2}$ can be found in Figures 4 and 6 for immunoblot (Figs. 4A,B and 6A) and in-gel fluorescence detection (Fig. 4C,D). If a stimulant induces endogenous $\mathrm{H}_{2} \mathrm{O}_{2}$ production, an increase in sulfenylated proteins should be observed. Finally, a protocol for cells (HepG2) stimulated with $\mathrm{H}_{2} \mathrm{O}_{2}$ is provided so that the user may develop and hone their skills as necessary (Figs. 5A,B and 6B). DMSO vehicle control lanes should have negligible background signal. In cell lysate samples that have been precleared with NeutrAvidin agarose resin, signal may still be evident at $\sim 66$ and $97 \mathrm{kDa}$. In fact, these bands may be observed for unlabeled and probe-labeled samples. This is not cause for major concern and indicates that biotinylated proteins could not be completely depleted from samples. Results can be considered successful if the signal from probelabeled samples is higher than the control lanes, and if a stimulant-dependent increase of signal is observed. If the user finds it difficult to observe the desired stimulant-dependent response, a number of solutions can be explored. Simple adjustments such as changing the 
concentration of the probe, stimulant, labeling times, and protein loading should be considered (see Strategic Planning or Critical Parameters and Troubleshooting for more detailed explanations). The sensitivity of the detection method can also be a factor and thus, immunoblot and in-gel fluorescence should both be explored.

\section{Time Considerations}

The experiments outlined in this protocol typically require between 2 and 3 days from labeling to detection of sulfenylated proteins. Experiments with purified protein in vitro (Basic Protocol 1) can be paused after sample buffer has been added to click chemistry reactions (6 to $8 \mathrm{hr}$ ). Immunoblot or in-gel fluorescence detection can be carried out on the same or following day, depending on the user. Live-cell experiments (Basic Protocols 2 and 3) can be paused at the methanol or methanol/chloroform precipitation step (6 to $8 \mathrm{hr}$ ). For live-cell experiments, detection of sulfenylated proteins should be performed on the next day after samples have been resuspended. Additionally, the user may pause the experiment directly after the cells are labeled with DAz-2 or DYn-2. After washing cells to remove labeling medium, cell pellets can be harvested and stored at $-80^{\circ} \mathrm{C}$ (see Basic Protocol 2, step 10). However, after cell lysis, it is recommended that the experiment be continued to the precipitation step to avoid compromising the click chemistry reaction. Basic Protocol 2 can be adapted for other cell types, but each system will require optimization.

\section{Acknowledgements}

The authors acknowledge funding from the Camille Henry Dreyfus Teacher Scholar Award (to K.S.C.) and the American Heart Association Scientist Development Award (0835419N to K.S.C.) for support of this work. The authors also gratefully acknowledge Crystal L. Yan for her assistance with experiments.

\section{Literature Cited}

Benitez, L.V. and Allison, W.S. 1974. The inactivation of the acyl phosphatase activity catalyzed by the sulfenic acid form of glyceraldehyde 3 -phosphate dehydrogenase by dimedone and olefins. J. Biol. Chem. 249:6234-6243.

Chan, T.R., Hilgraf, R., Sharpless, K.B., and Fokin, V.V. 2004. Polytriazoles as copper(I)-stabilizing ligands in catalysis. Org. Lett. 6:2853-2855.

Charron, G., Zhang, M.M., Yount, J.S., Wilson, J., Raghavan, A.S., Shamir, E., and Hang, H.C. 2009. Robust fluorescent detection of protein fatty-acylation with chemical reporters. J. Am. Chem. Soc. 131:4967-4975.

Crane, E.J. 3rd, Vervoort, J., and Claiborne, A. 1997. 13C NMR analysis of the cysteinesulfenic acid redox center of enterococcal NADH peroxidase. Biochemistry 36:86118618.

Depuydt, M., Leonard, S.E., Vertommen, D., Denoncin, K., Morsomme, P., Wahni, K., Messens, J., Carroll, K.S., and Collet, J.F. 2009. A periplasmic reducing system protects single cysteine residues from oxidation. Science 326:1109-1111.

Dickinson, B.C. and Chang, C.J. 2011. Chemistry and biology of reactive oxygen species in signaling or stress responses. Nat. Chem. Biol. 7:504511.

Gallagher, S., Winston, S.E., Fuller, S.A., and Hurrell, J.G. 2008. Immunoblotting and immunodetection. Curr. Protoc. Mol. Biol. 83:10.8.110.8.28.

Lambeth, J.D. 2004. NOX enzymes and the biology of reactive oxygen. Nat. Rev. Immunol. 4:181189.

Leonard, S.E. and Carroll, K.S., 2011. Chemical omics' approaches for understanding protein cysteine oxidation in biology. Curr. Opin. Chem. Biol. 15:88-102.

Leonard, S.E., Reddie, K.G., and Carroll, K.S. 2009. Mining the thiol proteome for sulfenic acid modifications reveals new targets for oxidation in cells. ACS Chem. Biol. 4:783-799.

Leonard, S.E., Garcia, F.J., Goodsell, D.S., and Carroll, K.S. 2011. Redox-based probes for protein tyrosine phosphatases. Angew. Chem. Int. Ed. Engl. 50:4423-4427.

Paulsen, C.E. and Carroll, K.S. 2009. Chemical dissection of an essential redox switch in yeast. Chem. Biol. 16:217-225.

Paulsen, C.E. and Carroll, K.S. 2010. Orchestrating redox signaling networks through regulatory cysteine switches. ACS Chem. Biol. 5:47-62.

Paulsen, C.E., Truong, T.H., Garcia, F.J., Homann, A., Gupta, V., Leonard, S.E., and Carroll, K.S. 2011. Peroxide-dependent sulfenylation of the EGFR catalytic site enhances kinase activity. Nat. Chem. Biol. 8:57-64.

Poole, L.B., Klomsiri, C., Knaggs, S.A., Furdui, C.M., Nelson, K.J., Thomas, M.J., Fetrow, J.S., Daniel, L.W., and King, S.B. 2007. Fluorescent and affinity-based tools to detect cysteine sulfenic acid formation in proteins. Bioconjug. Chem. 18:2004-2017.

Reddie, K.G. and Carroll, K.S. 2008. Expanding the functional diversity of proteins through cysteine oxidation. Curr. Opin. Chem. Biol. 12:746-754.

Reddie, K.G., Seo, Y.H., Muse, W.B. III, Leonard, S.E., and Carroll, K.S. 2008. A chemical approach for detecting sulfenic acid-modified proteins in living cells. Mol. Biosyst. 4:521-531.

Rhee, S.G. 2006. Cell signaling. $\mathrm{H}_{2} \mathrm{O}_{2}$, a necessary evil for cell signaling. Science 312:1882-1883.
Bioorthogonal

Reporters for

Protein

Sulfenylation

\section{1}


Rhee, S.G., Bae, Y.S., Lee, S.R., and Kwon, J. 2000. Hydrogen peroxide: A key messenger that modulates protein phosphorylation through cysteine oxidation. Sci. STKE 2000:pe1.

Rostovtsev, V.V., Green, L.G., Fokin, V.V., and Sharpless, K.B. 2002. A stepwise huisgen cycloaddition process: Copper(I)-catalyzed regioselective "ligation" of azides and terminal alkynes. Angew. Chem. Int. Ed. Engl. 41:25962599.

Salmeen, A., Andersen, J.N., Myers, M.P., Meng, T.C., Hinks, J.A., Tonks, N.K., and Barford, D. 2003. Redox regulation of protein tyrosine phosphatase 1B involves a sulphenyl-amide intermediate. Nature 423:769-773.

Saxon, E. and Bertozzi, C.R. 2000. Cell surface engineering by a modified Staudinger reaction. Science 287:2007-2010.

Seo, Y.H. and Carroll, K.S. 2009. Profiling protein thiol oxidation in tumor cells using sulfenic acidspecific antibodies. Proc. Natl. Acad. Sci. U.S.A. 106:16163-16168.

Seo, Y.H. and Carroll, K.S. 2011. Quantification of protein sulfenic acid modifications using isotope-coded dimedone and iododimedone. Angew. Chem. Int. Ed. Engl. 50:1342-1345.

Speers, A.E., Adam, G.C., and Cravatt, B.F. 2003. Activity-based protein profiling in vivo using a copper(i)-catalyzed azide-alkyne [3+2] cycloaddition. J. Am. Chem. Soc. 125:46864687.

Truong, T.H., Garcia, F.J., Seo, Y.H., and Carroll, K.S. 2011. Isotope-coded chemical reporter and acid-cleavable affinity reagents for monitoring protein sulfenic acids. Bioorg. Med. Chem. Lett. 21:5015-5020.

Wilson, J.P., Raghavan, A.S., Yang, Y.Y., Charron, G., and Hang, H.C. 2011. Proteomic analysis of fatty-acylated proteins in mammalian cells with chemical reporters reveals $\mathrm{S}$-acylation of histone H3 variants. Mol. Cell Proteomics 10:M110.001198.

Winterbourn, C.C. 2008. Reconciling the chemistry and biology of reactive oxygen species. Nat. Chem. Biol. 4:278-286.

Wood, Z.A., Schroder, E., Robin Harris, J., and Poole, L.B. 2003. Structure, mechanism and regulation of peroxiredoxins. Trends Biochem. Sci. 28:32-40.

Yeh, J.I., Claiborne, A., and Hol, W.G. 1996. Structure of the native cysteine-sulfenic acid redox center of enterococcal NADH peroxidase refined at $2.8 \AA$ resolution. Biochemistry 35:99519957.

Zheng, M., Aslund, F., and Storz, G. 1998. Activation of the OxyR transcription factor by reversible disulfide bond formation. Science 279:1718-1721.
Bioorthogonal Reporters for Protein Sulfenylation 